\title{
AUNC
}

Zabytkoznawstwo i Konserwatorstwo XLIX

Toruń 2018

DOI: http://dx.doi.org/10.12775/AUNC_ZiK.2018.010

\section{Rodzaje opracowań w technice mazerunku na wybranych przykładach dziewiętnastowiecznej stolarki kościelnej z terenów Pomorza Zachodniego}

\author{
MARCIN FAUSEK \\ e-mail:mfausek@wp.pl \\ JUSTYNA OLSZEWSKA-ŚWIETLIK \\ Zakład Technologii i Technik Malarskich \\ Wydział Sztuk Pięknych, UMK w Toruniu \\ e-mail: justolsz@umk.pl \\ ORCID: 0000-0001-5892-8619
}

Key words: graining techniques, church joinery, organ prospect, West Pomerania Słowa kluczowe: mazerunek, stolarka kościelna, prospekt organowy, Pomorze Zachodnie

\section{Abstract}

Types of application of graining techniques in selected examples of 19th-century church joinery from West Pomerania

This works presents the graining technique of selected and representative 19th century church joinery from West Pomerania. Graining, which is a form of painting decoration, was made on different substrates to imitate the surface of precious wood. In Western Pomerania, mostly oak wood, less nutty, was imitated.

In order to get a deeper understanding of the graining technique, selected historic church joinery was analyzed. A set of chemical and instrumental studies was performed. Particularly helpful was the analysis by the energy-dispersive X-ray microanalysis SEM-EDS. 


\begin{abstract}
Abstrakt
Artykuł prezentuje techniki mazerunków z wybranej i reprezentatywnej dziewiętnastowiecznej stolarki kościelnej z terenów Pomorza Zachodniego. Mazerunek, czyli zdobniczą technikę malarską stosowano na różnych podłożach dla imitowania usłojonej powierzchni szlachetnego drewna. Na Pomorzu Zachodnim odwzorowywano głównie usłojenie drewna dębowego, rzadziej orzechowego.

W celu dogłębnego poznania techniki mazerunków, wybrane obiekty zabytkowe poddano specjalistycznym badaniom laboratoryjnym. Wykonano zestaw badań chemicznych i instrumentalnych, szczególnie pomocne okazało się zastosowanie energodyspersyjnej analizy rentgenowskiej z użyciem mikrosondy elektronowej SEM-EDS.
\end{abstract}

Artykuł dotyczy technologii i techniki mazerunków z wybranej i reprezentatywnej dziewiętnastowiecznej stolarki kościelnej z terenów Pomorza Zachodniego. Mazerunek, czyli zdobniczą technikę malarską stosowano na różnych podłożach dla imitowania usłojonej powierzchni szlachetnego drewna. $\mathrm{Na}$ Pomorzu Zachodnim odwzorowywano głównie usłojenie drewna dębowego, rzadziej orzechowego.

W celu dogłębnego poznania techniki mazerunków, wybrane obiekty zabytkowe poddano specjalistycznym badaniom laboratoryjnym. Wykonano zestaw badań chemicznych i instrumentalnych, szczególnie pomocne okazało się zastosowanie energodyspersyjnej analizy rentgenowskiej z użyciem mikrosondy elektronowej SEM-EDS (fot. 9, 10) ${ }^{1}$.

Historia techniki imitacji szlachetnego drewna sięga czasów starożytnych, znana i stosowana była w Egipcie. W Europie pojawiła się w wieku XVI, następnie wolno ewoluowała i jej rozkwit przypadł dopiero na przełom XIX i XX stulecia, kiedy cieszyła się dużą popularnością. Powstało wtedy wiele obiektów z mazerowaną powierzchnią, wydano także liczne podręczniki opisujące tę technikę, głównie w języku niemieckim. W drugiej połowie XIX wieku zaczęto coraz częściej odchodzić od wiernego naśladowania rzeczywistego usłojenia, przedstawiając powierzchnię drewna w sposób bardziej wrażeniowy i fantazyjny lub nazbyt uproszczony i schematyczny. Technika ta, obecnie zapomniana, została wyparta w XX wieku przez nadruk.

\footnotetext{
Analizy SEM-EDS wykonali Grzegorz Trykowski i Elżbieta Szczepańska z Pracowni Analiz Instrumentalnych na Wydziale Chemii UMK w Toruniu, wykorzystując skaningowy mikroskop elektronowy (ang. scanning electron microscope - SEM) produkcji LEO Electron Microscopy Ltd, Anglia, model 1430 VP z 2001 r., wyposażony w spektrometr rentgenowski (ang. energy dispersive X-ray spectrometer - EDX) Quantax 200 z detektorem XFlash 4010 produkcji Bruker AXS, Niemcy z 2008 r.
} 
Technikę mazerunku dzieli się na wodną oraz olejną. Niezależnie od jej wersji używano tych samych materiałów, z tym że wodna wymagała większej umiejętności malarza ze względu na szybsze wysychanie wody aniżeli oleju. Przy opracowaniu malarskim posługiwano się szczotkami, pędzlami, sztyftami gumowymi i skórzanymi, gumowymi i stalowymi grzebieniami, wałkami i kartonami oraz gąbkami. Stosowano dwie metody wykonania mazerunków: „wybierania lazuru” oraz „nadruku”. Opracowanie mazerowania metodą „wybierania lazuru” polegało na usunięciu nadmiaru farby z powierzchni za pomocą specjalistycznych narzędzi i wyeksponowaniu podkładu z oddaniem charakterystycznego dla danego gatunku drewna usłojenia. Efektem takiego opracowania było uzyskanie niepowtarzalnego „usłojenia”. Natomiast po zastosowaniu metody „nadruku”, polegającej na odciśnięciu farby z pieczęci, można zaobserwować powtarzalność „usłojenia drewna” oraz większą sztywność modelunku malarskiego².

W artykule omówiono obiekty z sześciu kościołów: w Czaplinku (fot. 1), Barzowicach (fot. 2), Bobolicach (fot. 3), Korzystnie (fot. 4), Karcinie (fot. 5, 6) oraz w Ratajkach (fot. 7, 8), w których znajduje się mazerowane zabytkowe wyposażenie, czyli ołtarze, ambony, prospekty organowe, empory i ławki. Wspólnym mianownikiem elementów stolarki we wszystkich wymienionych kościołach jest pochodzenie $\mathrm{z}$ tego samego warsztatu organmistrzowskiego - prowadzonego przez Barnima Grüneberga ze Szczecina. Warsztat ten był jedną z kilku firm prężnie działających na terenie Pomorza Zachodniego od drugiej połowy XIX do początku XX wieku i na przestrzeni około pięćdziesięciu lat ściśle współpracował z wieloma lokalnymi zakładami stolarskimi i malarskimi. Dla kościoła w Ratajkach wykonano w tym warsztacie stolarkę $\mathrm{z}$ imitacją usłojenia drewna orzechowego, natomiast dla pozostałych pięciu kościołów - elementy wyposażenia imitujące drewno dębowe.

Szafa organowa wraz z emporą są jedynymi zachowanymi do dziś obiektami w czaplineckim kościele (fot. 1), które udekorowano mazerunkiem. Tabliczka sygnująca warsztat organmistrzowski, w którym powstały - umieszczona nad drugim manuałem w szafie organowej - informuje, że zostały one wykonane w roku 1862 . Oba obiekty zbudowano z drewna sosnowego. Wysezonowane drewno zostało starannie przygotowane - precyzyjnie

Ludmiła Tymińska-Widmer, „Technika mazerunku w zdobieniu sprzętów kościelnych. Zagadnienia technologiczne, funkcjonalne i konserwatorskie”, w: Zabytkowa stolarka we wnętrzach sakralnych i jej problematyka konserwatorska, red. Janusz Krawczyk (Toruń: Wydawnictwo Naukowe Uniwersytetu Mikołaja Kopernika 2010), 322. 
przycięto wszystkie elementy, zmontowano je i wyszlifowano powierzchnie. Następnie nałożono szerokim i płaskim pędzlem cienką warstwę zaprawy emulsyjnej, która miała wygładzić nierówności powierzchni (sęki, uskoki) i jednocześnie stanowiła podkład pod dekorację mazerunkową. Do wykonania polichromii w technice mazerunku użyto farb o spoiwie olejno-żywicznym i metody „wybierania lazuru”. Na zaprawę nałożono na płasko jasnobrązową warstwę podkładu, po jej wyschnięciu położono kolejną warstwę i posługując się odpowiednimi narzędziami (szczotki, grzebienie i gumowe sztyfty, szczecinowe pędzle) wybrano nadmiar jeszcze niewyschniętej farby, tworząc w ten sposób imitację usłojenia drewna dębowego. Miejscami powierzchnię topowano bardzo rzadkim pędzlem szczecinowym, aby oddać naturalny wygląd komórek naczyniowych drewna dębowego. Partie przy „rdzeniu” opracowano dodatkowo przez odciśnięcie elastycznych pieczęci z nałożoną brązową farbą. Mazerunek, sporządzony z wysoką starannością i w sposób rzeczywisty odwzorowuje naturalny charakter dębiny. Oba obiekty dosyć starannie zawerniksowano i dlatego zacieki występują w znikomych ilościach.

W Barzowicach imitacja usłojenia drewna jest wyeksponowana na zachowanym do dziś prospekcie organowym wraz z balustradami chórowymi oraz ławkach, natomiast ołtarz został przemalowany (fot. 2). Na podstawie zachowanych archiwalnych zdjęć z początku XX wieku należy sądzić, że w skład mazerowanego wyposażenia w 1912 roku wchodziły również nieistniejące obecnie fragmenty empory wzdłuż nawy oraz ambona. Taki sam sposób opracowania dekoracyjnej powierzchni wszystkich elementów wyposażenia w tym kościele potwierdza, że zostały wykonane przez jeden warsztat. Zachowane obiekty zmontowano z wysezonowanej sośniny - jej powierzchnię odpowiednio przygotowano (przez wyheblowanie i wyszlifowanie) do nałożenia podkładu pod mazerunek. Podkład nałożono szerokim, płaskim pędzlem jako cienką warstwę jasnej zaprawy emulsyjnej, która miała również wygładzić nierówności powierzchni drewna. Następnie nałożono płasko i równomiernie laserunkowo jasną farbę, którą pozostawiono do wyschnięcia. Imitację usłojenia wykonano farbami o spoiwie olejno-żywicznym metodą „wybierania lazuru”, przez wybieranie nadmiaru farby za pomocą specjalistycznych narzędzi, czyli grzebieni, gumowych sztyftów i szczecinowych pędzli, oraz przetopowano w niektórych miejscach powierzchnię warstwy malarskiej rzadkim szczeciniakiem. Partie przy „rdzeniu dębu” opracowano dodatkowo odciskając elastyczne pieczęcie z nałożoną brązową farbą. Mazerunek sporządzono nieco schematycznie, w pośpiechu i z mniejszą precyzją, 
aniżeli w Czaplinku. Werniks końcowy nałożono bardzo niestarannie i nierównomiernie, w rezultacie powstało bardzo dużo zacieków.

W Bobolicach w skład obecnie zachowanego ruchomego wyposażenia z 1886 roku należy zaliczyć ołtarz główny, ambonę, ławki oraz prospekt organowy wraz z emporą (fot. 3). Niestety pod koniec XX stulecia obiekty te zostały pozbawione mazerunku - $\mathrm{w}$ trakcie przeprowadzonych w tym czasie na terenie kościoła kompleksowych prac remontowo-konserwatorskich całkowicie usunięto przemalowania wraz z mazerunkiem. Pozostawiono jedynie, w celu urozmaicenia kolorystyki w kościele, żółte przemalowania na kapitelach kolumn na prospekcie organowym. Ponadto powierzchnie z nieusuniętym mazerunkiem wraz z przemalowaniami zachowały się jeszcze w śladowej ilości - w miejscach trudno dostępnych. W 2010 roku w ramach konserwacji prospektu organowego usunięto przemalowania i wyeksponowano na kapitelach warstwę malarską imitującą usłojenie drewna.

Mazerowane elementy wyposażenia kościelnego w Bobolicach zostały wykonane z wysezonowanego i wyheblowanego drewna sosnowego. Prawdopodobnie wszystkie obiekty wewnątrz bobolickiej świątyni wykonano w tej samej technice i w tym samym warsztacie stolarskim. Na powierzchnię sośniny nałożono szerokim i płaskim pędzlem cienką warstwę jasnej zaprawy emulsyjnej, która miała wygładzić nierówności. Na zaprawę nałożono równomiernie, w cienkiej warstwie, jasny podkład. Następnie wykonano imitację usłojenia dębiny farbami o spoiwie olejno-żywicznym metodą „wybierania lazuru", przez wybieranie położonego równomiernie na płasko nadmiaru farby za pomocą specjalistycznych narzędzi, oraz przesmarowano i przetopowano warstwę malarską w niektórych miejscach rzadkim szczecinowym pędzlem w celu uzyskania „komórek naczyniowych”, charakterystycznych dla tego gatunku drzewa. Najprawdopodobniej fragmenty przy „rdzeniu” opracowano za pomocą odciśnięcia elastycznych pieczęci z nałożoną brązową farbą. Na podstawie zachowanych śladowych ilości oryginalnej warstwy malarskiej, dosyć topornie położonej, można przypuszczać, że imitacja została wykonana bez dokładnego studium z natury i z tendencją do schematycznego przedstawienia usłojenia szlachetnego drewna. Warstwę malarską zawerniksowano.

W Korzystnie mazerunek jest wyeksponowany na prospekcie organowym oraz balustradzie chórowej (fot. 4), natomiast na ołtarzu głównym imitacja usłojenia drewna została przemalowana. Obiekty te są datowane na rok 1867. Należy dodać, że szafa organowa powstała zaledwie pięć lat później niż obiekt z Czaplinka i według tego samego projektu z 1860 roku - jego autorem 
był architekt ze szkoły schinklowskiej Karl Johann Bogislaw Lüdecke - lecz sposób opracowania mazerunku jest nieco inny i wykonany bardziej mechanicznie aniżeli w Czaplinku i Karcinie.

Mazerowane elementy stolarki kościelnej zostały wykonane z wysezonowanego i wyheblowanego drewna sosnowego. Wszystkie obiekty sporządzono w tej samej technice i w jednym warsztacie. Na powierzchnię sośniny nałożono szerokim i płaskim pędzlem cienką warstwę jasnego podkładu, który miał częściowo wygładzić nierówności. Imitację usłojenia dębiny wykonano farbami o spoiwie olejno-żywicznym metodą „wybierania lazuru”, przez wybieranie położonego równomiernie na płasko nadmiaru farby za pomocą specjalistycznych narzędzi, oraz przesmarowano i przetopowano w niektórych miejscach rzadkim, szczecinowym pędzlem w celu uzyskania „komórek naczyniowych” charakterystycznych dla tego gatunku drzewa. W obrębie „rdzenia dębu” wprowadzono dodatkowo imitację za pomocą odciśnięcia elastycznych pieczęci z nałożoną brązową farbą. Opracowaną warstwę malarską zawerniksowano. Niestety w trakcie wykonywania mazerunku popełniono błąd technologiczny i powstało bardzo dużo wczesnych spękań w formie „krokodylej skórki”.

W Karcinie mazerunek został zachowany na prospekcie organowym wraz z balustradą chórową oraz ławkach (fot. 5,6 ), natomiast na powierzchni ambony monochromatyczną warstwę malarską przemalowano. Tabliczka sygnująca warsztat organmistrzowski, znajdująca się nad manuałem w kontuarze szafy organowej, informuje, iż organy oraz mazerowane wyposażenie pochodzą z 1862 roku. Na podstawie analizy zarówno wizualnej, jak i laboratoryjnej stwierdzono, że mazerunek został sporządzony tak samo jak w Czaplinku i w tym samym okresie. Można w związku z tym wnioskować, że w obu kościołach działał ten sam wykonawca ruchomego wyposażenia.

Elementy wyposażenia świątyni zostały podobnie zrobione. Wysezonowane drewno sosnowe starannie przygotowano - precyzyjnie przycięto każdy element, zmontowano i wyszlifowano powierzchnię. Po zakończeniu prac stolarskich na powierzchnię drewna nałożono szerokim, płaskim pędzlem cienką warstwę zaprawy emulsyjnej, która miała wygładzić nierówności (sęki, uskoki).Zaprawę pokryto równomiernie i cienko jasnym podkładem. Następnie wykonano polichromię w technice mazerunku, stosując farby o spoiwie olejno-żywicznym i metodę „wybierania lazuru”. Na zaprawę nałożono na płasko warstwę brązowej farby i przy użyciu narzędzi (szczotek, grzebieni, gumowych sztyftów i szczecinowych pędzli) wybrano nadmiar jeszcze niewyschniętej farby, odwzorowując w ten sposób usłojenie drewna dębowego. 
Miejscami przetopowano powierzchnię warstwy malarskiej bardzo rzadkim, szczecinowym pędzlem, aby oddać naturalny wygląd komórek naczyniowych dębiny. Partie przy „rdzeniu dębu” wykonano dodatkowo za pomocą odciśnięcia elastycznych pieczęci z nałożoną brązową farbą. Mazerunek sporządzono z dużą starannością, oddając w sposób realistyczny powierzchnię dębowego drewna. Obiekty prawidłowo zawerniksowano.

W Ratajkach mazerunek jest wyeksponowany na obiektach ruchomych z 1868 roku, czyli na ołtarzu, ambonie i prospekcie organowym (fot. 7, 8), jedynie balustrada chórowa została przemalowana. Elementy wyposażenia świątyni zostały wykonane w jednym warsztacie i w podobny sposób.

Wysezonowane drewno sosnowe zostało precyzyjnie przycięte, przygotowane elementy zmontowano i wyszlifowano ich powierzchnię. Następnie szerokim i płaskim pędzlem nałożono równomiernie cienką warstwę zaprawy emulsyjnej, która miała wygładzić wszelkie nierówności powierzchni i jednocześnie stanowić podkład pod imitację usłojenia drewna. Polichromię w technice mazerunku wykonano farbami o spoiwie olejno-żywicznym metodą „wybierania lazuru”. Na jasny podkład nałożono płasko warstwę brązowej farby i przy użyciu specjalistycznych szczotek, grzebieni oraz szczecinowych pędzli wybrano jej nadmiar, naśladując w ten sposób usłojenie charakterystyczne dla orzecha. W obrębie „rdzenia” usłojenia wykonano w dwojaki sposób: za pomocą elastycznych pieczęci oraz ręcznie przy użyciu pędzla. Mazerunek sporządzono raczej starannie, w sposób schematyczny oddając wygląd drewna liściastego, ze wskazaniem na orzech. Obiekty prawidłowo zawerniksowano, dzięki temu zacieki oraz miejsca niezawerniksowane występowały w znikomych ilościach.

Przed przystąpieniem do badań laboratoryjnych pobrano próbki z warstwy malarskiej wraz z zaprawą z kościelnych prospektów organowych z Czaplinka (próbka nr 1), Barzowic (próbka nr 2), Karcina (próbka nr 3) i Korzystna (próbka nr 4) .

Wykonano zdjęcia mikroskopowe przekrojów próbek w świetle VIS i skaningowe (SEM) oraz mapping przekrojów próbek (fot. 9, 10), w których określono rozmieszczenie poszczególnych pierwiastków. Ponadto przeprowadzono analizę spektralną składu pierwiastkowego próbek. Zdjęcia w świetle VIS

Próbki zatopiono w żywicy „Duracryl Plus” prod. Spofa Dental - Czechy i wyeksponowano przekrój poprzeczny przez zeszlifowanie nadmiaru żywicy. Budowa stratygraficzna imitacji usłojeń drewna określona została w świetle widzialnym VIS oraz za pomocą energodyspersyjnej analizy rentgenowskiej z zastosowaniem mikrosondy elektronowej SEM-EDS. 
dały pełny obraz przekroju stratygraficznego poszczególnych warstw: wyodrębniono zaprawę oraz nałożoną warstwowo polichromię, w której występuje jasny podkład i zewnętrzna warstwa imitująca usłojenie drewna. Badania SEM-EDS przekrojów próbek wykazały rozmieszczenie poszczególnych pierwiastków. Za pomocą tej analizy określono skład pierwiastkowy w wybranych punktach na przekrojach poprzecznych próbek. W próbce nr 1 wykazano obecność następujących pierwiastków: $\mathrm{C}, \mathrm{O}, \mathrm{Mg}, \mathrm{Al}, \mathrm{Si}, \mathrm{S}, \mathrm{Ca}, \mathrm{Fe}, \mathrm{Zn}$. W próbce nr 2 zidentyfikowano $\mathrm{C}, \mathrm{O}, \mathrm{Al}, \mathrm{Si}, \mathrm{K}, \mathrm{Ca}, \mathrm{Fe}, \mathrm{Zn}, \mathrm{Ba}, \mathrm{Pb}$. W próbce $\mathrm{nr} 3$ odnotowano $\mathrm{C}, \mathrm{O}, \mathrm{Al}, \mathrm{Si}, \mathrm{Ca}, \mathrm{Fe}, \mathrm{Zn}, \mathrm{Pb}$. W próbce $\mathrm{nr} 4$ stwierdzono następujący skład pierwiastkowy: C, O, Al, Si, Fe, Zn, Ba, Pb.

Analizy SEM-EDS wykazały, że prospekt organowy w Czaplinku (próbka nr 1) oraz balustrada chórowa zostały pokryte warstwą zaprawy wraz $\mathrm{z}$ mazerunkiem. W zaprawie użyto bieli ołowiowej $\left(2 \mathrm{PbCO}_{3}{ }^{*} \mathrm{~Pb}(\mathrm{OH})_{2}\right)$ i kredy $\left(\mathrm{CaCO}_{3}\right)$, natomiast w warstwie malarskiej zastosowano biel ołowiową $\left(2 \mathrm{PbCO}_{3}{ }^{*} \mathrm{~Pb}(\mathrm{OH})_{2}\right)$, biel cynkową $(\mathrm{ZnO})$, ugier $\left(\mathrm{Fe}_{2} \mathrm{O}_{3}{ }^{*} \mathrm{nH}_{2} \mathrm{O}\right)$ oraz brąz żelazowy $\left(\mathrm{Fe}_{2} \mathrm{O}_{3}{ }^{*} \mathrm{nH}_{2} \mathrm{O}, \mathrm{Al}, \mathrm{Si}\right.$ ). W Barzowicach (próbka nr 2) prospekt organowy wraz z emporą i pozostałymi elementami ruchomego wyposażenia kościelnego zostały pokryte zaprawą, w której zidentyfikowano jedynie kredę $\left(\mathrm{CaCO}_{3}\right)$, natomiast $\mathrm{w}$ warstwie mazerunku stwierdzono obecność tych samych pigmentów, co w Korzystnie, czyli bieli ołowiowej $\left(2 \mathrm{PbCO}_{3}{ }^{*} \mathrm{~Pb}(\mathrm{OH})_{2}\right)$, bieli cynkowej $(\mathrm{ZnO})$, bieli zawierającej siarczan baru $\left(\mathrm{BaSO}_{4}\right)$, ugru $\left(\mathrm{Fe}_{2} \mathrm{O}_{3}{ }^{*} \mathrm{nH}_{2} \mathrm{O}\right)$ oraz brązu żelazowego $\left(\mathrm{Fe}_{2} \mathrm{O}_{3}{ }^{*} \mathrm{nH}_{2} \mathrm{O}, \mathrm{Al}, \mathrm{Si}\right)$. Na obiektach w Karcinie (próbka nr 3) zastosowano w zaprawie, podobnie jak w Czaplinku, biel ołowiową $\left(2 \mathrm{PbCO}_{3}{ }^{*} \mathrm{~Pb}(\mathrm{OH})_{2}\right)$ i kredę $\left(\mathrm{CaCO}_{3}\right)$, natomiast w warstwie mazerunku biel ołowiową $\left(2 \mathrm{PbCO}_{3}{ }^{*} \mathrm{~Pb}(\mathrm{OH})_{2}\right)$, biel cynkową $(\mathrm{ZnO})$, ugier $\left(\mathrm{Fe}_{2} \mathrm{O}_{3}{ }^{*} \mathrm{nH}_{2} \mathrm{O}\right)$ oraz brąz żelazowy $\left(\mathrm{Fe}_{2} \mathrm{O}_{3}{ }^{*} \mathrm{nH}_{2} \mathrm{O}, \mathrm{Al}, \mathrm{Si}\right)$. Prospekt organowy w Korzystnie (próbka nr 4) oraz pozostałe elementy stolarki kościelnej nie zostały pokryte zaprawą, a jedynie bardzo cienkim podkładem pod mazerunek. W warstwie malarskiej użyto tych samych pigmentów, co w Czaplinku i Karcinie, z tym że wykorzystano dodatkowo pigment zawierający siarczan baru, co by wskazywało na litopon lub samą biel barytową - konieczne jest przeprowadzenie dokładniejszych badań w celu zidentyfikowania konkretnej bieli ${ }^{4}$. Wykazano udział bieli ołowiowej $\left(2 \mathrm{PbCO}_{3}{ }^{*} \mathrm{~Pb}(\mathrm{OH})_{2}\right)$, bieli cynkowej $(\mathrm{ZnO})$, bieli zawierającej siarczan baru $\left(\mathrm{BaSO}_{4}\right)$, ugru $\left(\mathrm{Fe}_{2} \mathrm{O}_{3}{ }^{*} \mathrm{nH}_{2} \mathrm{O}\right)$ oraz brązu żelazowego $\left(\mathrm{Fe}_{2} \mathrm{O}_{3}{ }^{*} \mathrm{nH}_{2} \mathrm{O}\right.$, $\mathrm{Al}, \mathrm{Si})$.

4 Piotr Rudniewski, Pigmenty i ich identyfikacja (Warszawa: Akademia Sztuk Pieknych,1995), 42. 
Przeprowadzone badania potwierdziły i poszerzyły informacje dotyczące rodzaju zastosowanych technik mazerunku oraz budowy technologicznej mazerowanej warstwy malarskiej wraz z zaprawą zawarte w literaturze opracowanej na przełomie XIX i XX wieku. W wyniku analiz opisanych w niniejszej publikacji stwierdzono, że do wykonania mazerunków na stolarce kościelnej w XIX wieku stosowano popularne ówcześnie pigmenty, takie jak: kreda, biel ołowiowa, biel cynkowa, biel zawierająca siarczan baru oraz ugier i brązowy pigment żelazowy ${ }^{5}$. Zachowywano jednak pewną dowolność w doborze najczęściej używanych pigmentów (tab. 1, 2), ponieważ badania wykazały, że zaprawę obiektów w Barzowicach stanowi sama kreda, natomiast w Czaplinku i Karcinie skład zaprawy został wzbogacony o biel ołowiową. Podobnie sytuacja wygląda ze składem chemicznym warstwy malarskiej: w Korzystnie i Barzowicach użyto bieli zawierającej siarczan baru, którego nie zastosowano w Czaplinku i Karcinie. Pozostałe pigmenty - biel cynkowa, ugier i brązowy pigment żelazowy - występują w warstwie polichromii wszystkich mazerunków na badanych obiektach.

Sposób opracowania mazerunku jest we wszystkich badanych obiektach bardzo zbliżony. Najpierw na ich drewniane podłoże (poza elementami wyposażenia w Korzystnie) została cienko nałożona jedna warstwa zaprawy emulsyjnej. Podstawowym składnikiem zaprawy jest kreda, do której w Czaplinku i Karcinie dodano biel ołowiową. Po przygotowaniu zaprawy położono równomiernie w jednej cienkiej warstwie, za pomocą płaskiego pędzla, jaśniejszą olejno-żywiczną farbę składającą się z mieszaniny bieli ołowiowej, cynkowej i rzadziej bieli zawierającej w swym składzie bar (biel barytowa lub litopon). Na tak przygotowanym podkładzie opracowano imitację usłojenia szlachetnego drewna: nałożono farbę składającą się z mieszaniny ugru i umbry i następnie szybkimi ruchami zbierano jej niewyschnięty nadmiar posługując się szczotką, pędzlem o twardym lub średnim włosiu oraz grzebieniami i gumowymi sztyftami. W dalszej kolejności opracowano „naczynia” drewna przez topowanie powierzchni oraz odciśnięto elastyczne pieczęcie z nałożoną farbą lub malowano pędzlem „rdzeń drewna”. Uzyskany w ten sposób mazerunek, w zależności od tego, czy wykonany prymitywnie, czy umiejętnie odwzorowujący naturę, miał imitować określony gatunek drewna, czyli dąb lub orzech. Na końcu, po wyschnięciu mazerowanej powierzchni, obiekty zabezpieczono werniksem.

5 Carl Christen, Die Technik der Holzmalerei (Hannover: Schäfer, 2000), 6-7. 
Tabela 1. Wykaz zidentyfikowanych pigmentów

\begin{tabular}{|c|c|c|c|c|}
\hline Warstwa & $\begin{array}{l}\text { Czaplinek } \\
\text { próbka nr } 1\end{array}$ & $\begin{array}{l}\text { Barzowice } \\
\text { próbka nr } 2\end{array}$ & $\begin{array}{c}\text { Karcino } \\
\text { próbka nr } 3\end{array}$ & $\begin{array}{l}\text { Korzystno } \\
\text { próbka nr } 4\end{array}$ \\
\hline Zaprawa & $\begin{array}{l}\text { biel ołowiowa } \\
\left(2 \mathrm{PbCO}_{3}{ }^{*} \mathrm{~Pb}(\mathrm{OH})_{2}\right) \\
\text { kreda }\left(\mathrm{CaCO}_{3}\right)\end{array}$ & kreda $\left(\mathrm{CaCO}_{3}\right)$ & $\begin{array}{l}\text { biel ołowiowa } \\
\left(2 \mathrm{PbCO}_{3}{ }^{*} \mathrm{~Pb}(\mathrm{OH})_{2}\right) \\
\text { kreda }\left(\mathrm{CaCO}_{3}\right)\end{array}$ & Brak \\
\hline $\begin{array}{l}\text { Warstwa } \\
\text { malarska }\end{array}$ & $\begin{array}{l}\text { ugier }\left(\mathrm{Fe}_{2} \mathrm{O}_{3}{ }^{*} \mathrm{nH}_{2} \mathrm{O}\right) \\
\text { brąz żelazowy } \\
\left(\mathrm{Fe}_{2} \mathrm{O}_{3}{ }^{*} \mathrm{nH}_{2} \mathrm{O}, \mathrm{Al}, \mathrm{Si}\right)\end{array}$ & $\begin{array}{l}\text { biel ołowiowa } \\
\left(2 \mathrm{PbCO}_{3}{ }^{*} \mathrm{~Pb}(\mathrm{OH})_{2}\right) \\
\text { biel cynkowa }(\mathrm{ZnO}) \\
\text { biel zawierająca } \\
\text { siarczan baru } \\
\left(\mathrm{BaSO}_{4}\right) \\
\text { ugier }\left(\mathrm{Fe}_{2} \mathrm{O}_{3}{ }^{*} \mathrm{nH}_{2} \mathrm{O}\right) \\
\text { brazz żelazowy } \\
\left(\mathrm{Fe}_{2} \mathrm{O}_{3}{ }^{*} \mathrm{nH}_{2} \mathrm{O}, \mathrm{Al}, \mathrm{Si}\right)\end{array}$ & $\begin{array}{l}\text { ugier }\left(\mathrm{Fe}_{2} \mathrm{O}_{3}{ }^{*} \mathrm{nH}_{2} \mathrm{O}\right) \\
\text { braz żelazowy } \\
\left(\mathrm{Fe}_{2} \mathrm{O}_{3}{ }^{*} \mathrm{nH}_{2} \mathrm{O}, \mathrm{Al}, \mathrm{Si}\right)\end{array}$ & $\begin{array}{l}\text { biel ołowiowa } \\
\left(2 \mathrm{PbCO}_{3}{ }^{*} \mathrm{~Pb}(\mathrm{OH})_{2}\right) \\
\text { biel cynkowa }(\mathrm{ZnO}) \\
\text { biel zawierająca } \\
\text { siarczan baru } \\
\left.(\mathrm{BaSO})_{4}\right) \\
\text { ugier }\left(\mathrm{Fe}_{2} \mathrm{O}_{3}{ }^{*} \mathrm{nH}_{2} \mathrm{O}\right) \\
\text { braz żelazowy } \\
\left(\mathrm{Fe}_{2} \mathrm{O}_{3}{ }^{*} \mathrm{nH}_{2} \mathrm{O}, \mathrm{Al}, \mathrm{Si}\right)\end{array}$ \\
\hline
\end{tabular}

Tabela 2. Charakterystyka mazerunku

\begin{tabular}{|l|l|l|l|l|l|l|}
\hline \multicolumn{1}{|c|}{ Dane } & Czaplinek & Barzowice & Karcino & Korzystno & Bobolice & Ratajki \\
\hline Datowanie & 1862 r. & 1912 r. & 1862 r. & 1867 r. & 1886 r. & $1868 \mathrm{r}$. \\
\hline $\begin{array}{l}\text { Kolor } \\
\text { mazerunku }\end{array}$ & $\begin{array}{l}\text { jasny } \\
\text { brazz }\end{array}$ & $\begin{array}{l}\text { jasny } \\
\text { brąz }\end{array}$ & $\begin{array}{l}\text { jasny } \\
\text { brąz }\end{array}$ & $\begin{array}{l}\text { ciemny } \\
\text { brąz }\end{array}$ & $\begin{array}{l}\text { ciemny } \\
\text { brąz }\end{array}$ & $\begin{array}{l}\text { jasny } \\
\text { brąz }\end{array}$ \\
\hline $\begin{array}{l}\text { Rodzaj } \\
\text { imitowanego } \\
\text { drewna }\end{array}$ & dab & dąb & dabb & dab & dab & orzech \\
\hline
\end{tabular}




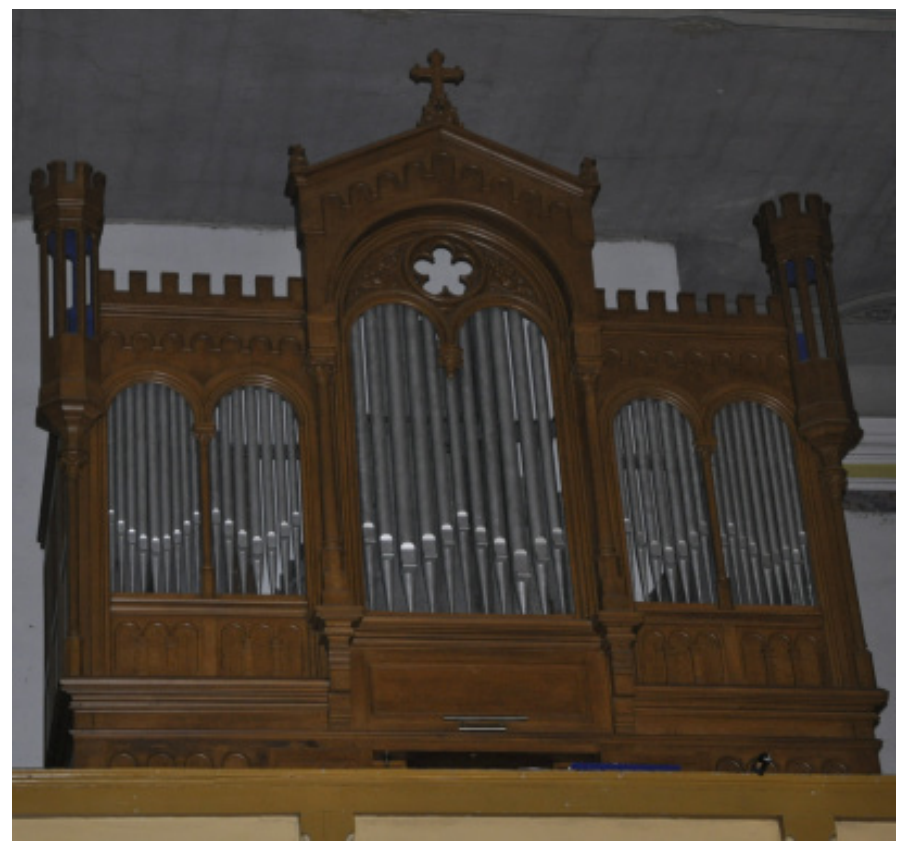

Fot. 1. Kościół w Czaplinku, prospekt organowy, stan obecny. Fot. M. Fausek

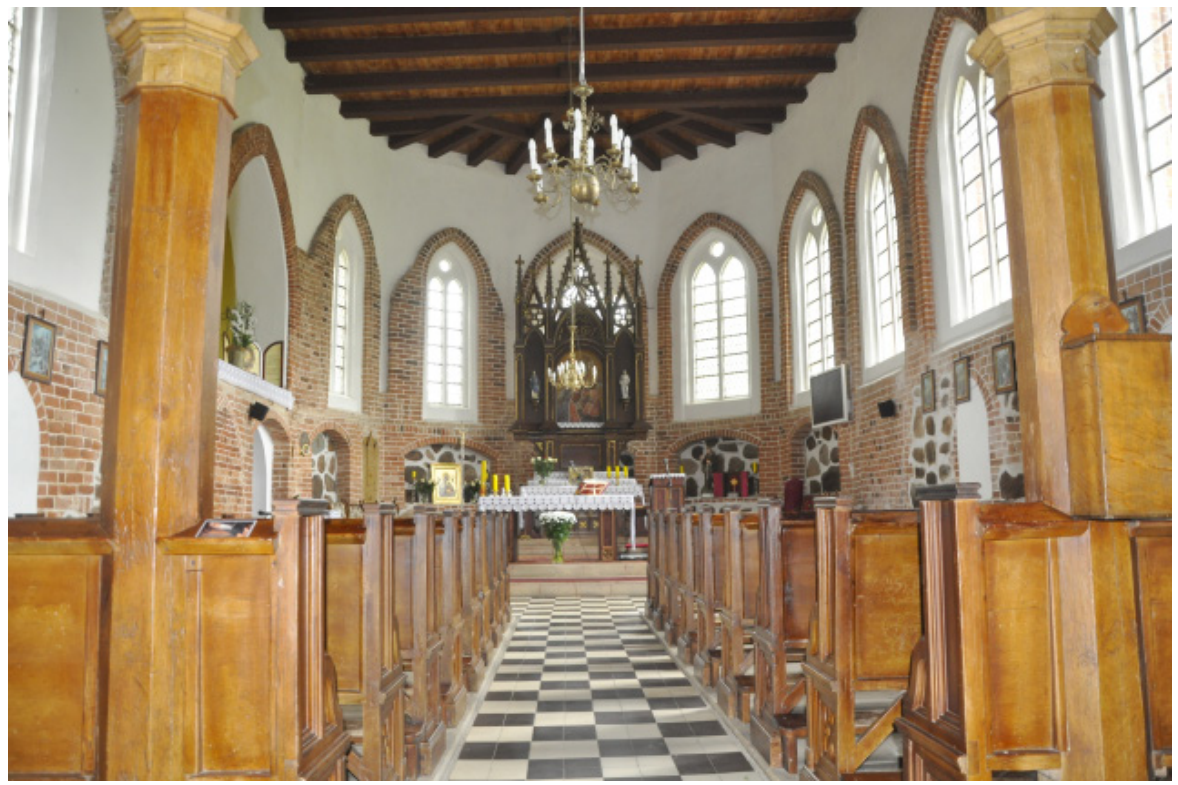

Fot. 2. Kościół w Barzowicach, ławki, filary empory i ołtarz, stan obecny. Fot. M. Fausek 


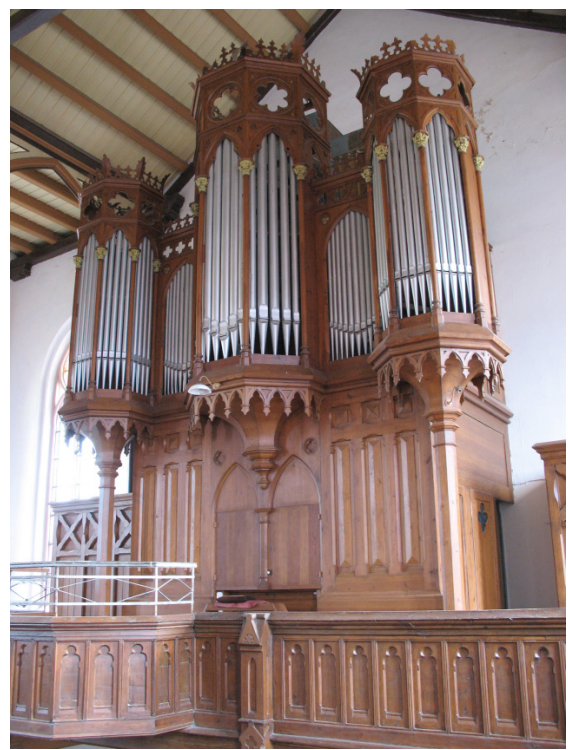

Fot. 3. Kościół w Bobolicach, prospekt organowy, stan obecny. Fot. M. Fausek

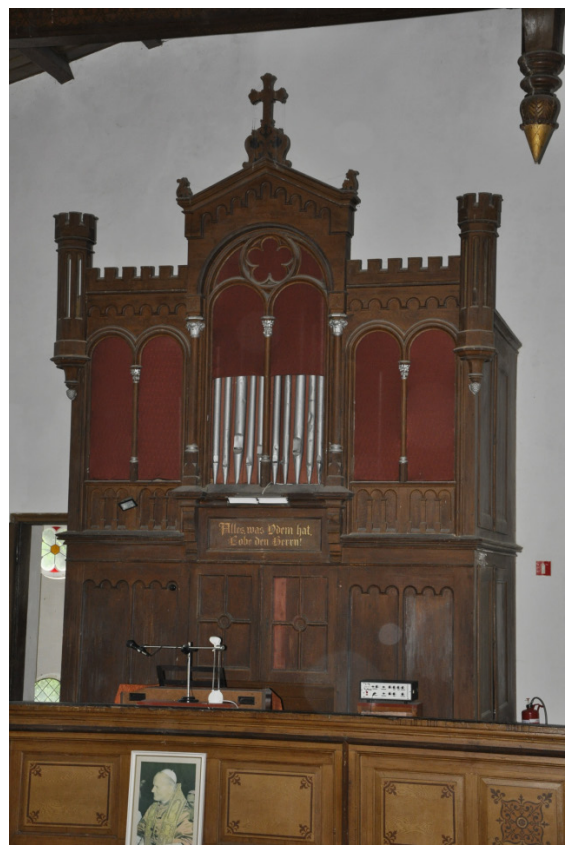

Fot. 4. Kościół w Korzystnie, prospekt organowy, stan obecny. Fot. M. Fausek 


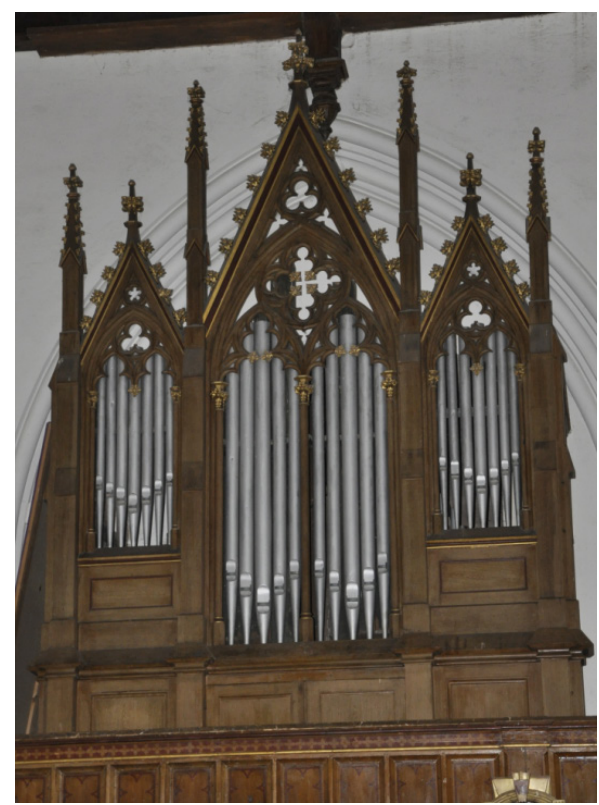

Fot. 5. Kościół w Karcinie, prospekt organowy, stan obecny. Fot. M. Fausek

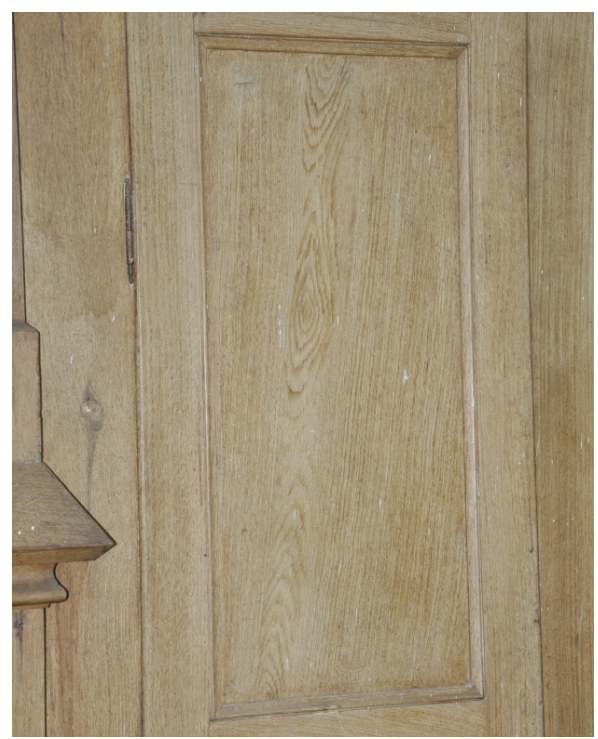

Fot. 6. Kościół w Karcinie, fragment szafy organowej, mazerunek imitujący drewno dębowe, stan obecny. Fot. M. Fausek 


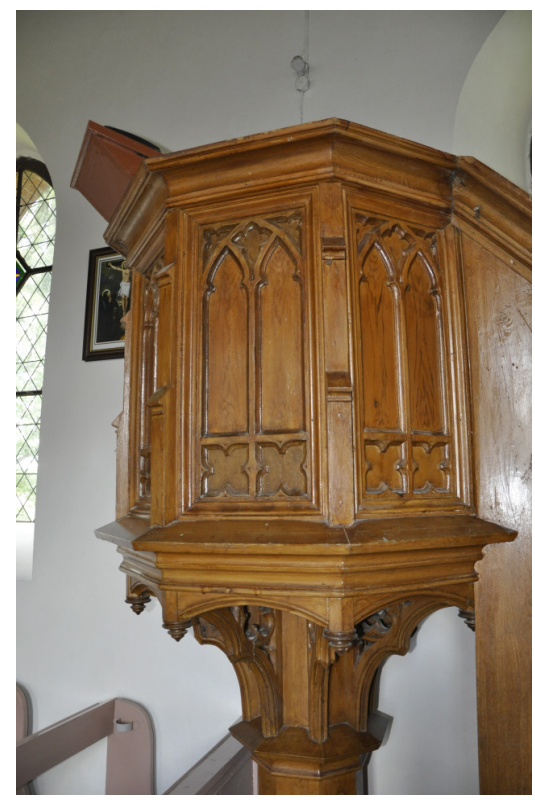

Fot. 7. Kościół w Ratajkach, ambona, stan obecny. Fot. M. Fausek

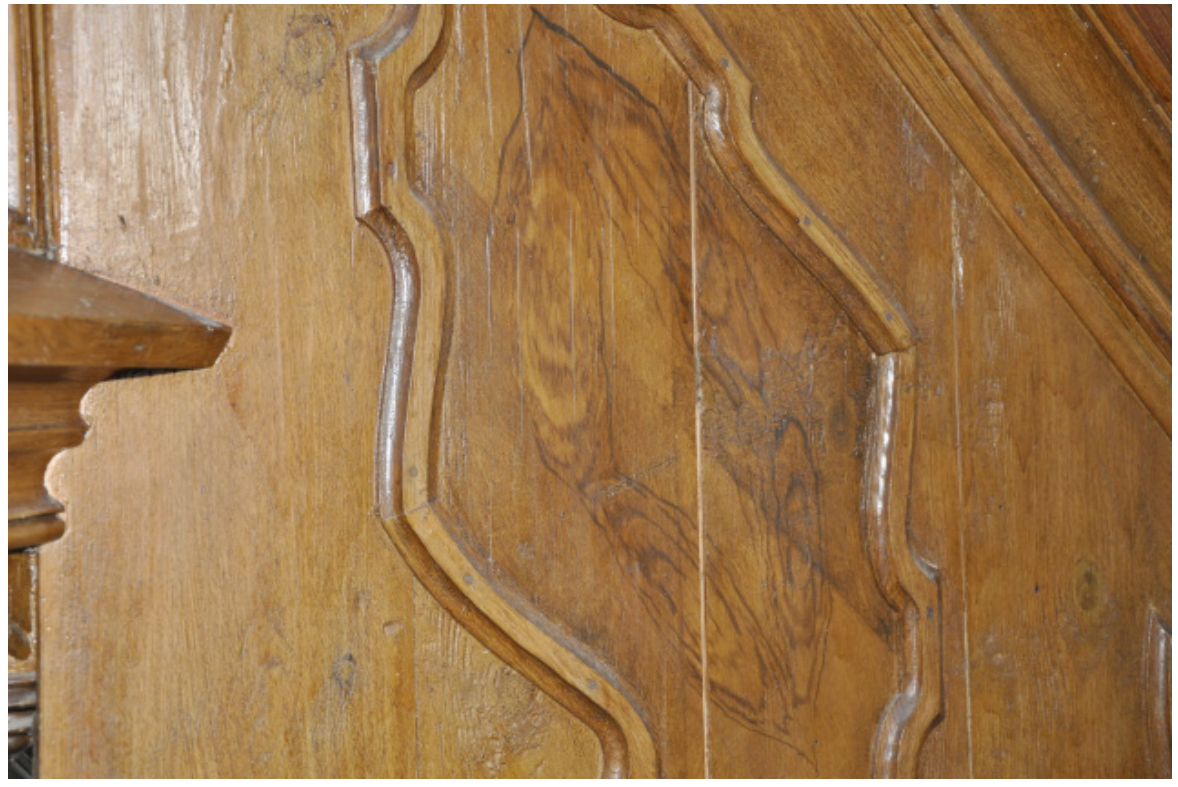

Fot. 8. Kościół w Ratajkach, fragment balustrady ambony, mazerunek imitujący drewno orzechowe, stan obecny. Fot. M. Fausek 

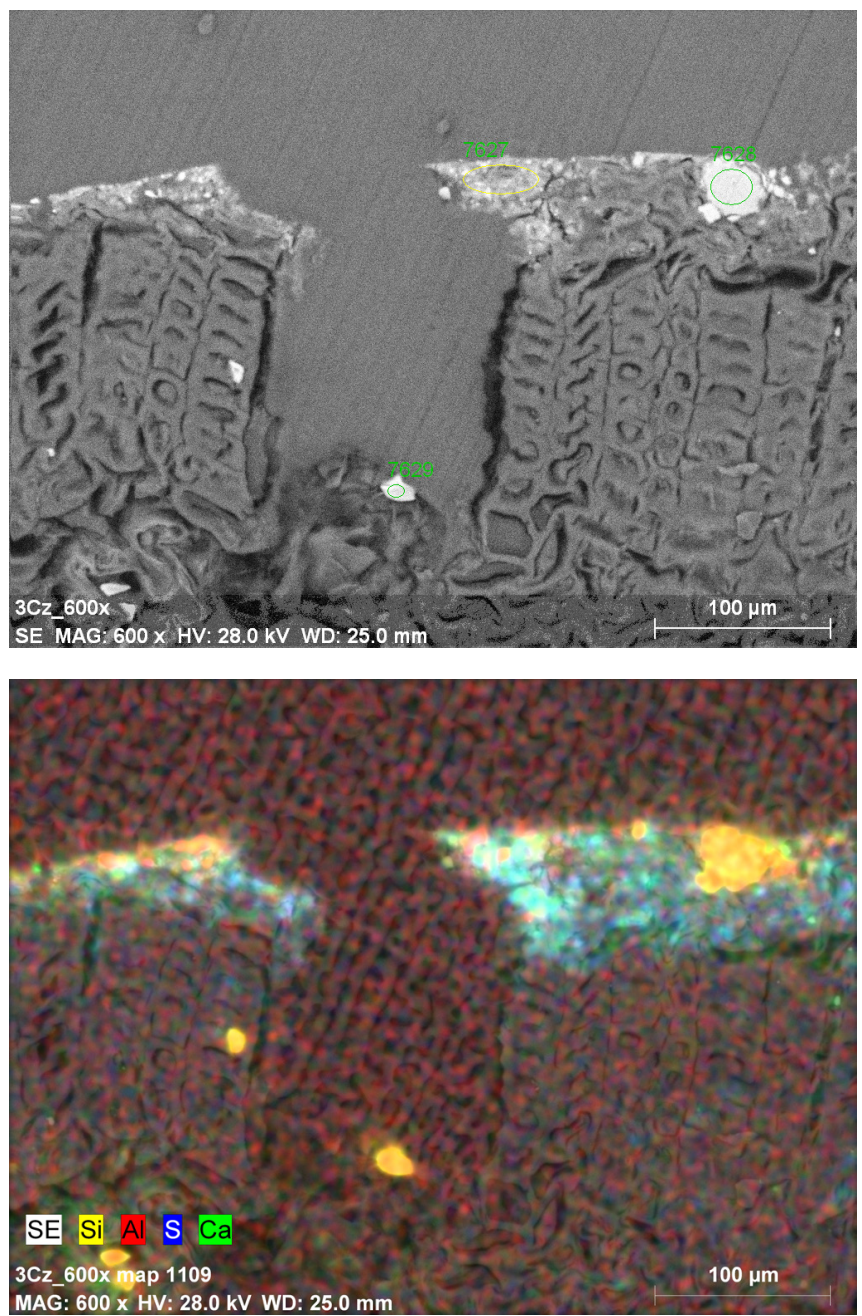

Fot. 9, 10. Zdjęcie skaningowe (SEM) oraz mapping przekroju próbki drewna, zaprawy i warstwy malarskiej z prospektu organowego w kościele w Czaplinku ukazujące rozkład pierwiastków $\mathrm{Si}, \mathrm{Al}, \mathrm{S}, \mathrm{Ca} .1$ - drewno iglaste; 2 - zaprawa: biel ołowiowa $\left(2 \mathrm{PbCO}_{3}{ }^{*} \mathrm{~Pb}(\mathrm{OH})_{2}\right)$, kreda $\left(\mathrm{CaCO}_{3}\right) ; 3$ - jasna warstwa malarska: biel ołowiowa $\left(2 \mathrm{PbCO}_{3}{ }^{*} \mathrm{~Pb}(\mathrm{OH})_{2}\right)$, biel cynkowa (ZnO), ugier $\left(\mathrm{Fe}_{2} \mathrm{O}_{3}{ }^{*} \mathrm{nH}_{2} \mathrm{O}\right) 4$ - ciemna warstwa malarska: brąz żelazowy $\left(\mathrm{Fe}_{2} \mathrm{O}_{3}{ }^{*} \mathrm{nH}_{2} \mathrm{O}, \mathrm{Al}, \mathrm{Si}\right)$ 


\section{Bibliografia}

Christen, Carl, Die Technik der Holzmalerei. Hannover: Schäfer, 2000.

Rudniewski, Piotr, Pigmenty i ich identyfikacja. Warszawa: Akademia Sztuk Pięknych, 1995.

Tymińska-Widmer, Ludmiła, „Technika mazerunku w zdobieniu sprzętów kościelnych. Zagadnienia technologiczne, funkcjonalne i konserwatorskie”, 321-328. W Zabytkowa stolarka we wnętrzach sakralnych i jej problematyka konserwatorska, red. Janusz Krawczyk. Toruń: Wydawnictwo Naukowe Uniwersytetu Mikołaja Kopernika, 2010. Wall, William E., Practical Graining. Frankfurt am Main: Outlook Verlag GmbH, Deutschland, 2018. 